\title{
Business Schools' Use of CSR as a Corporate Marketing Strategy
}

\author{
Anne Ellerup Nielsen, PhD, Associate Professor, aen@asb.dk \\ Christa Thomsen,PhD, Associate Professor, ct@asb.dk \\ Centre for Corporate Communication, Aarhus School of Business, University of Aarhus, \\ Fuglesangs Alle 4, DK-8210 Aarhus V, Tel.: + 4589486688.
}

\begin{abstract}
Business schools and other public and private organisations are increasingly expected not only to comply with rules, regulations and expectations of responsibility but also to focus on managing stakeholders' impressions of the organisation and on building corporate reputation. One way of doing this is through CSR communication.

This paper is motivated by a recent interest within public sector management and communication research of studying higher education strategic communication and marketing (Hemsley-Brown and Oplatka, 2006). On the basis of studies on higher education institutions' strategic communication, CSR and marketing on the web, the paper identifies first a number of criterias for evaluating the success of modern business schools' communication of CSR on the web. Next, it analyses the occurrence of selected internally vs. externally oriented CSR keywords in the sections of 1) education, 2) research and 3) management (or 'about us') of 17 business schools' websitse, the purpose being to find out how business schools in different contexts prioritise CSR communication on their websites, and whether the communication is consistent.
\end{abstract}

Finally, the paper discusses the findings in light of the success criterias set up in the first part of the paper.

KEYWORDS: business schools, corporate social responsibility (CSR), strategic communication

\section{INTRODUCTION}

One way of studying the use of corporate social responsibility (CSR) as a central theme in the contemporary discussions about the relationship between business universities or schools and society is to analyse how they communicate about their efforts regarding CSR. Among the many 
different ways by which organisations communicate about these efforts, how they do so on their website stands out (Esrock and Leichty, 1998; Esrock and Leichty, 2000; Pollach, 2003; Welcomer et al., 2003; Nielsen, 2005). This article is based on the idea that how business schools use and write about issues of CSR on their website provides insight in their approach to dealing with these issues. CSR being a contextual and dynamic concept (Carroll, 1999; Matten and Moon, 2008) it might be expected that there are both similarities and differences between business schools in this respect (Apéria, Brønn and Schultz, 2004). Further, business schools may take different positions allowing them to stand out (Volkwein and Sweitzer, 2006).

The paper is motivated by a recent interest within public sector management and communication research of studying higher education strategic communication and marketing (Hemsley-Brown and Oplatka, 2006). Today, business schools and other public and private organisations are expected not only to comply with rules, regulations and expectations of responsibility but also to focus on managing stakeholders' impressions of the organisation and on building corporate reputation. One way of doing this is through CSR initiatives and communication (Fombrun 2005; Vidaver-Cohen 2007).

In order to explore such issues, we analysed how a sample of major European Academy for Business in Society (EABIS) member business schools ${ }^{1}$ communicate about CSR on their website. Our theoretical framework draws on literature on higher education strategic communication and strategic CSR communication and situates business schools within the new context of competition. The empirical part explores how selected business schools communicate about their efforts regarding CSR on their websites. It analyses the occurrence of selected CSR keywords in the sections of 1) education or programmes, 2) research and 3) management, 'about us', strategy or similar of the website. A discussion of our findings in light of the success criteria inspired by the litterture concludes that further research is needed in order to confirm our impression that business schools still have a long way to go towards learning how to act strategically in respect of CSR communication.

The mission of a business school is to "teach and train participants (undergraduate students, young managers and executives) in the most advanced knowledge in business theory and practice, while contributing to the development and dissemination of new knowledge through research" (Durand

\footnotetext{
${ }^{1}$ Our sample consists of 28 business schools who are partners, sponsors or members of The European Academy of Business in Society, EABIS (as of 1st April 2009).
} 
and Dameron, 2008: 84). In order to do so, business schools try to attract high level participants and excellent faculty. Marketing and reputation management is thus a key self-reinforcing ingredient of the business and modern educational institutions increasingly recognise that they need to market themselves in a climate of global competition (Vidaver-Cohen, 2007; Durand and Dameron, 2008). A range of studies on business schools' strategic communication, CSR communication and marketing on the web have inspired our analysis (e.g. Corley and Gioia, 2000; Boyle, 2004; Matten and Moon, 2004; Hemsley-Brown and Oplatka,2006;Volkwein and Sweitzer, 2006;Vidaver-Cohen, 2007; Christensen, Peirce, Hartman, Hoffman and Carrier,2007;Wæraas, 2008). They demonstrate that corporate marketing and branding are important tools to use for higher education institutions in order to build strong corporate brands that are distinctive and consistent, not least because, public organisations often are characterised by contradictory and inconsistent values and multiple identities. This makes the ideal of consistency difficult to achieve. Thus, it is argued that public organisations will benefit more from branding on the basis of inconsistent values and multiple identities rather than trying to promote one set of values and one identity at the expense of others. This argument is also in line with recent research in corporate branding (e.g. Balmer and Greyser, 2002).

Research on CSR communication via web focuses on the web's agenda-setting potential (Esrock and Leichty 1998) or on organisations' self-presentation as socially responsible citizens (e.g. Esrock and Leichty, 1998; Esrock and Leichty, 2000; Pollach 2003; Pollach, 2005). Most of these studies have investigated how large Fortune 500 corporations use the web for communicating CSR, using quantative content analysis in order to describe CSR approaches and content patterns.

On the basis of the abovementioned literature on business schools strategic communication and marketing efforts and literature on corporations' CSR communication on the web we summarise the recommendations to higher education strategic communication as follows:

In the context of increasing competition for home-based and overseas students higher educational institutions need to market and position themselves on specific characteristics, e.g. specific representations of CSR which are valued by their stakeholders.

Organisations who want to present themselves as socially responsible organisations should recognise the web as a strategic impression management tool. However, they must be aware of the main challenge of communicating CSR, i.e. how to communicate consistently about 
CSR. This means that CSR must be conceived as a fundamental value embedded in the management of the organisation.

These recommendations allow us to set up two 'minimal' criterias for evaluating the success of modern business schools' CSR communication on their websites:

1. Business schools should communicate about their efforts regarding CSR on their websites.

2. The communication should be consistent or integrated which means that the schools should communicate CSR not only in the external sections (research and education) but also in the management or strategy sections in order to show that CSR is integrated in the value set and overall strategy.

Our research questions are motivated by the above recommendations and the success criterias we have set up for modern business schools' CSR communication on their websites.

\section{PURPOSE AND RESEARCH QUESTIONS}

This paper aims to investigate in a pilot study selected European business schools' strategic communication of CSR on their websites, a topic which has not earlier - as far as we are informed been submitted to academic research. The purpose of the paper is also to discuss or reflect upon the particular context and possible theoretical models of business schools' strategic CSR communication. Thus, we ask the following questions:

$R Q$ 1: To which extent do business schools communicate about their efforts regarding CSR on their websites?

$R Q$ 2: How consistent is business schools' communication of CSR on the web?

Before presenting our analysis and our findings, we outline our approach and methodology.

\section{APPROACH AND METHODOLOGY}

In line with Matten and Moon (2004), we assume that CSR would mostly be understood as an umbrella term for a broad set of synonyms and overlapping concepts reflecting both business and society relations and business ethics. According to Matten and Moon (2004: 324), the choice of the particular terminology of corporate social responsibility was determined by the fact that key 
institutional players (such as the 2002 founded European Academy of Business in Society), key media and to a growing degree, corporate oriented publications seem to have made this term an increasingly popular label. The findings of the survey conducted by Matten and Moon (2004) of corporate social responsibility education in Europe echo these assumptions as indeed the variety of topics in the field proved very broad. For our key word search, we have selected five frequently used CSR synonyms, the first three concepts in an external perspective (external stakeholders) and the last two in an internal perspective (internal stakeholders):

- Corporate Social Responsibility

- Sustainability

- Corporate Citizenship

- Code of conduct

- Corporate Governance

We first conducted a CSR keyword search in English on the business schools' websites in order to confirm our belief that CSR is relevant to European business schools. This search paved the way for our pilot study of the research, education and management (or similar) sections of the website, in which study we have focused on the occurrence of CSR sites ${ }^{2}$. Our study is based on a comparative design: taking three categories as the units of analysis, the study design allows for comparison across areas, and between business schools and countries. It allows us to see how business schools in different contexts prioritise CSR communication on their websites, and whether the communication is consistent.

As indicated above corporate websites were selected because they are ideal for studying the use of corporate social responsibility (CSR) as a central theme in the contemporary discussions about the relationship between universities and society. The content found on business schools' websites is under the management of the schools, and thus there is total control over the message. This means that websites allow universities to establish a strategic position via communications.

\footnotetext{
${ }^{2}$ Steps in the collection of data: 1 ) domain and sub-domain establishment related to the three selected categories (research, education and management), e.g. for London Business School: london.edu (start page) and london.edu/facultyandresearch/, london.edu/programmes/, london.edu/theschool/, 2) Google advanced search machine (http://www.google.dk/advanced search?hl=da) used to determine the number of pages with CSR related content (baseline), 3) CSR-hits (selected key words: corporate social responsibility, sustainability, corporate citizenship, code of conduct and corporate governance).
} 
A major sample of 28 European business schools and universities was drawn from EABIS' academic network, suggesting that these institutions are more likely than others to integrate CSR into their management strategy and to run research projects and study programmes within CSR. Accordingly, these institutions are also expected to communicate about their CSR objectives and practices on their websites. They all practice teaching and research up to the Ph.D. level A minor sample of 17 was extracted from the major sample for technological reasons in that the content management system used for the websites is based on comparable portal systems. Variables used for the analysis are segmented in subsites or portals covering the following content areas: a) school/university management, b) educational programmes, modules and courses and c) research projects and activities. For full universities with a business faculty the search was undertaken within the subsites or portals representing the business faculty. However, in cases where no separate business faculty/school management section or portal existed, the search was based on the general university section for the management part of CSR.

\section{ANALYSIS: BUSINESS SCHOOLS' COMMUNICATION OF CSR ON THE WEB}

Below we draw a picture of the extent to which business schools communicate CSR on their corporate websites in general and within particular domains of activities that may be considered as primary to higher education and research institutions (Durand and Dameron, 2008: 84). In response to the strategic approach to CSR adopted for our study, the degree of alignment of CSR to the strategy of the institutions will be integrated in the analysis.

\section{Findings}

Table 1 indicates the ranking of the business schools/faculties in the major sample based on calculation of the total number of pages that contain at least one occurrence of CSR compared to the total number of pages on the business school or faculty website in general. In the following, pages containing a CSR keyword will be referred to as 'CSR pages'.

Table 2 is an illustration of the distribution of the total amount of CSR pages tracked within the domains of research, education and strategy, establishing the CSR ranking of the schools/faculties respectively. Using these tables we will provide an answer to the research questions raised above.

Amongst the 28 business schools/faculties of our major sample Ashridge Business School and Tias Nimbas Business School both stand out with more than $60 \%$ and $40 \%$ respectively of the schools' 
websites containing CSR keywords (table 1). If we consider the figures for the other schools and faculties, their CSR pages constitute less than $15 \%$ of the total amount of pages on the entire websites. Nottingham Business School appears as number three with $13 \%$ CSR pages. At the bottom of the list we find University of Cambridge and Esade Business School with less than 1\% CSR pages out of the total amount of pages on their websites. In the middle, schools and universities such as Solvay Business School, St. Petersburg State University School of Management and Durham Business School appear with an average of 3,5\% CSR pages as number 13, 14 and 15 respectively in the ranking list. Consequently, in respect of the extent to which the business schools and faculties communicate about CSR in general, there is an apparent span from $1 \%$ to $60 \%$ between the least and the most CSR communicating school/faculty. A glance at the 'country of origin' of the representatives does not seem to draw any pattern as to how much the business schools and faculties can be expected to communicate explicitly about CSR. This criteria may have had an influence, considering that the institutions are submitted to different national regulation systems that force higher education in some countries to contribute more actively to society than in others and consequently to communicate more explicitly about CSR (Matten \& Moon, 2008; Habisch, Jonker, Wegner \& Schmidpeter, 2005).

\begin{tabular}{|l|rrrl|}
\hline \multicolumn{5}{c|}{ CSR } \\
\hline Name & Total & Share & Rank & Country \\
\hline Vlerick Leuven Gent Management Nantes & 155 & $4,28 \%$ & 12 & Belgium \\
\hline Solvay Business School & 99 & $3,46 \%$ & 14 & Belgium \\
\hline Copenhagen Business School & 730 & $2,37 \%$ & 17 & Denmark \\
\hline Aarhus School of Business & 1870 & $2,46 \%$ & 16 & Denmark \\
\hline Helsinki School of Economics & 149 & $1,09 \%$ & 25 & Finland \\
\hline Turku School of Economics & 50 & $6,44 \%$ & 6 & Finland \\
\hline INSEAD Business School & 828 & $4,36 \%$ & 11 & France \\
\hline Audencia Ecole de Management School & 71 & $1,24 \%$ & 23 & France \\
\hline HEC & 62 & $1,50 \%$ & 22 & France \\
\hline Nyenrode Business University & 337 & $6,69 \%$ & 4 & Holland \\
\hline TiasNimbas Business School & 1350 & $44,26 \%$ & 2 & Holland \\
\hline Amsterdam Business School/Amsterdam University & 112 & $2,15 \%$ & 18 & Holland \\
\hline Bocconi Business University & 19 & $1,56 \%$ & 21 & Italy \\
\hline Milano School of Management & 90 & $6,57 \%$ & 5 & Italy \\
\hline Norwegian School of Management (BI) & 329 & $1,07 \%$ & 26 & Norway \\
\hline St. Petersburg State University School of Management & 55 & $4,10 \%$ & 13 & Russia \\
\hline Esade Business School & 362 & $0,52 \%$ & 27 & Spain \\
\hline IESE Business School/University of Navarra & 1940 & $6,14 \%$ & 7 & Spain \\
\hline
\end{tabular}




\begin{tabular}{|l|rrrl|}
\hline Ashridge Business School & 9800 & $61,25 \%$ & 1 & UK \\
\hline London Business School & 167 & $1,58 \%$ & 20 & UK \\
\hline Warwick Business School & 111 & $2,09 \%$ & 19 & UK \\
\hline University of Cambridge & 7680 & $0,31 \%$ & 28 & UK \\
\hline Durham Business School & 134 & $2,76 \%$ & 15 & UK \\
\hline Kingston Business School & 47 & $4,61 \%$ & 9 & UK \\
\hline Manchester Business School & 284 & $4,40 \%$ & 10 & UK \\
\hline Notthingham Business School/Nottingham University & 60 & $13,36 \%$ & 3 & UK \\
\hline Royal Holloway/London University & 823 & $1,11 \%$ & 24 & UK \\
\hline Bath University School of Management & 119 & $5,56 \%$ & 8 & UK \\
\hline
\end{tabular}

Table 1: CSR ranking list of EABIS academic network memi

As indicated above the consistency of CSR communication on the schools/faculties' corporate websites was investigated within the subpages of research, education and strategy. Table 2 gives a picture of the extent to which the 17 business schools/faculties drawn from the minor sample of our data a) communicate about CSR in the three different areas above, b) are consistent in aligning their CSR communication on research and education to the overall school/faculty CSR strategy and c) demonstrate an integrated approach to communicating their CSR research and education activities.

Question (a) can be answered by considering table 2 and the proportion of CSR pages in each of the three domains in comparison with the total amount of CSR pages (column 1-4), allowing to establish the internal ranking between the three domains for the 17 institutions (column 4-6). The answer to question (b) appears from the ranking gap between the proportion of CSR pages in research and education compared to the number of CSR pages in the strategy domain. Question c) is answered by comparing the score of CSR in education and research respectively.

In response of question (a), Ashridge Businesss School, who had the highest CSR communication score in the general ranking table, is also not surprisingly the most eager communicator of CSR within research, education and management. Bath University School of Strategy and London Business School both seems to have high ranks as number two in the list in CSR research and CSR education communication respectively. However, their scores are low for CSR and strategy with positions of zero and 11 out of 17 respectively. Concerning the score in CSR strategy communication, Nyenrode Business University is ranked in the top after Ashridge. At the bottom of 
the ranking HEC appears together with Copenhagen Business School who both manifest a relatively low score from 10 to 16 out of 17 in all three domains.

Question (b) related to the alignment of CSR research and education to CSR strategy leaves us with Ashridge at the top with a complete balance between the three domains. Warwick Business School had the second best balance with a gap of only 1 between their CSR research and strategy and education rank. This gap is also minor for Vlerik Leuven Gent Strategy Nantes for whom the gap is 3/2 between CSR research/education and strategy respectively. Schools and faculties who showed the largest gap between CSR communication in the strategy domain and in the two other domains are, apart from Bath University School of Management, Solvay Business School and Turku Business School who have no occurrences of CSR in the domain of management, IESE Business School, Bocconi Business University and London Business School for whom the gap between CSR strategy and CSR research or education communication is beyond 10. The important thing to notice is that their CSR strategic communication rank is far higher than their rank in CSR research or education. Interestingly enough, there are no schools and faculties obtaining a relatively low score in CSR strategic communication along with a very high score in their CSR research and education communication, except from those who have no CSR occurrences within the strategic domain.

The findings for question (c) answering whether there are gaps between the schools or faculties' CSR research and education communication still rank Ashridge at the top with no gap and IESE Business School at the bottom with a gap of 9 between the two domains. Warwick Business School and Vlerick Leuven Gent Strategy Nantes seem to balance the communication within the two domains with only a gap of 1 between them.

Summing up, we observe that the schools and faculties who are the best ranked in one or more of the domains are not necessarily those who appear as the most consistent in communicating about CSR in the three domains that we studied. 


\begin{tabular}{|c|c|c|c|c|c|c|c|}
\hline & \multicolumn{3}{|c|}{ Share of CSR-pages } & \multicolumn{3}{|c|}{ Internal rank rank } & \\
\hline Name & Res & du & Strat & Res & Edu & Strat & Country \\
\hline $\begin{array}{l}\text { Ashridge Business } \\
\text { School }\end{array}$ & $52,23 \%$ & $53,50 \%$ & $54,48 \%$ & 1 & 1 & 1 & UK \\
\hline $\begin{array}{l}\text { Bath University School } \\
\text { of Management }\end{array}$ & $30,86 \%$ & $11,33 \%$ & $0,00 \%$ & 2 & 4 & - & UK \\
\hline $\begin{array}{l}\text { Nyenrode Business } \\
\text { University }\end{array}$ & $21,57 \%$ & $4,84 \%$ & $24,22 \%$ & 3 & 7 & 2 & Holland \\
\hline Solvay Business School & $13,06 \%$ & $13,46 \%$ & $0,00 \%$ & 5 & 3 & - & Belgium \\
\hline London Business School & $10,29 \%$ & $33,89 \%$ & $1,41 \%$ & 7 & 2 & 11 & UK \\
\hline $\begin{array}{l}\text { INSEAD Business } \\
\text { School }\end{array}$ & $4,92 \%$ & $10,87 \%$ & $9,72 \%$ & 13 & 5 & 3 & France \\
\hline $\begin{array}{l}\text { Manchester Business } \\
\text { School }\end{array}$ & $11,65 \%$ & $1,84 \%$ & $6,17 \%$ & 6 & 13 & 5 & UK \\
\hline $\begin{array}{l}\text { Turku School of } \\
\text { Economics }\end{array}$ & $16,05 \%$ & $9,38 \%$ & $0,00 \%$ & 4 & 6 & - & Finland \\
\hline Durham Business School & $3,10 \%$ & $4,42 \%$ & $4,89 \%$ & 15 & 8 & 7 & UK \\
\hline $\begin{array}{l}\text { IESE Business } \\
\text { School/Univ. of Navarra }\end{array}$ & $9,96 \%$ & $0,79 \%$ & $6,17 \%$ & 8 & 17 & 6 & Spain \\
\hline $\begin{array}{l}\text { Vlerick Leuven Gent } \\
\text { Management Nantes }\end{array}$ & $5,48 \%$ & $3,11 \%$ & $1,52 \%$ & 12 & 11 & 9 & Belgium \\
\hline $\begin{array}{l}\text { Bocconi Business } \\
\text { University }\end{array}$ & $3,70 \%$ & $1,51 \%$ & $8,30 \%$ & 14 & 15 & 4 & Italily \\
\hline $\begin{array}{l}\text { Helsinki School of } \\
\text { Economics }\end{array}$ & $9,80 \%$ & $1,56 \%$ & $1,47 \%$ & 9 & 14 & 10 & Finland \\
\hline Esade Business School & $0,00 \%$ & $3,85 \%$ & $3,03 \%$ & 17 & 9 & 8 & Spain \\
\hline $\begin{array}{l}\text { Warwick Business } \\
\text { School }\end{array}$ & $5,61 \%$ & $2,13 \%$ & $0,54 \%$ & 11 & 12 & 12 & UK \\
\hline $\begin{array}{l}\text { Copenhagen Business } \\
\text { School }\end{array}$ & $6,14 \%$ & $0,91 \%$ & $0,41 \%$ & 10 & 16 & 13 & Denmark \\
\hline HEC & $0,44 \%$ & $3,76 \%$ & $0,00 \%$ & 16 & 10 & 14 & France \\
\hline
\end{tabular}

Table 2: Overview of Business Schools' share of CSR pages and ranking of CSR research, education and strategy communication on the web

\section{Limitations of research}

The findings above must be evaluated with some reservation. Firstly, since the application of CMS systems are highly individualised and complex, comparative search studies within theme portals and subpages do not necessarily track all relevant occurrences of a word or phrase that may occur 
elsewhere on a website, as e.g. in the 'news section' or other specific section. For the above study this means that for business schools and faculties having established e.g. 'community involvement' or 'sustainaibility' as a separate portal in their main menu (which is quite common for private companies but less frequent for higher education institutions), our keyword search will only cover such particular menus in the total account of CSR occurrences on a website, without accounting for the occurrences within the three domains of CSR research, strategy and education, unless they are subordinated to these portals or subpages. Secondly, the restriction of our search to the five selected CSR keywords above, excludes a number of potential CSR occurrences in our study which might appear when searching for other concepts, such as e.g. 'community involvement', 'social engagement', etc. Thirdly, as we limited our search to CSR keywords in English, non English institutions which do not have a complete parallel of their CSR pages in English, do not appear in the study with a complete representation of their CSR communication activities. Fourthly, we have not at this stage of the study taken into account relevant parameters such as the number of mouse clics it takes the user to access CSR information, which can be relevant for the evaluation of CSR as a branding instrument.

Taking in consideration these limitations, we will now discuss our findings in light of the success criteria set up in the first part of the paper.

\section{DISCUSSION AND CONCLUSIONS}

Our paper has investigated selected European business schools' communication of CSR on their websites

On the basis of a review of the literature on higher education strategic communication and strategic CSR communication, we have first identified two minimal criterias for evaluating the success of modern business schools' communication of CSR on their websites:

1. Business schools should communicate about their efforts regarding CSR on their websites.

2. The communication should be consistent or integrated which means that the schools should communicate CSR not only in the external sections (research and education) but also in the management ('about us' or strategy) sections in order to show that CSR is integrated in the value set and overall strategy of the school. 
Next, we have analysed the occurrence of three selected externally oriented CSR keywords (corporate social responsibility, sustainability, corporate citizenship) and two internally oriented CSR keywords (code of conduct, corporate governance) within three particular domains of activities that may be considered as primary to higher education and research institutions, i.e. research, education and strategic management.

In answer to the first question whether European business schools seem to comply with the agenda of communicating about their CSR activities on the web, our findings revealed that out of the total number of pages on a website, EABIS business schools members use less than $15 \%$ to communicate about CSR. For 21 out of 28 schools and faculties the share of web-pages containing as a minimum one of the five basic CSR keywords are below $5 \%$. In consequence, even amongst CSR motivated business schools, CSR cannot be seen as a predominant issue of communication. Furthermore, a glance at the two representatives who had a significant high amount of CSR on their websites (Ashridge and TiasNimbas) demonstrates that the high frequency is partly due to extensive cross-links to a master in sustainability and a sustainabibility foundation respectively. On the other hand, frequent reference to a CSR study-programme or a specific CSR activity or project, may be taken as a sign of proactive marketing on the web which is likely to generate awareness about innovative CSR initiatives not only to 'the market' (potential students), but to other stakeholders as well including the community, authorities, media, competitive schools and employees, etc.

(Maignan, Ferrell \& Ferrell 2001). Doing so helps to document what is going on in the organisation and to let stakeholders know how important CSR seems to be or not to be for the organisation.

Concerning the question of communicating consistently about CSR by aligning CSR research and education communication to strategic CSR management, we found that creating a communication balance within CSR research, education and strategy, in other words between what can be interpreted as higher education institutions' 'products' and the strategic management of the organisation, seems to be a challenge to some business schools. 3 out of 17 do have CSR research and study programmes without having anchored these activities in their overall strategy. Others seem to have prioritized CSR at the strategic management level without implementing CSR in their research and study programmes. Consequently, we may draw the conclusion that many business schools should use more efforts to balance their CSR communication in order to establish more consistent communication between their core activities and their mission and vision statement. This conclusion can equally be drawn from our findings concerning the gap between CSR research and 
education. Some of the business schools thus have prioritized CSR research rather than CSR education and vice versa. Assuming that ideally business schools teaching should be based on and supported by research findings, business schools and faculties should strive for a higher degree of consistency between these two core areas of activity. Effective communication of CSR necessitates a coordinated or integrated approach. Thus, our pilot study seems to indicate that business schools still have a long way to go towards learning how to act strategically in respect of CSR communication. However, further research, preferably of qualitative nature, is needed to confirm this hypothesis.

\section{REFERENCES}

Apéria, T., Brønn, P.S. and Schultz, M. (2004) 'A Reputation Analysis of the Most Visible Companies in the Scandinavian Countries', Corporate Reputation Review, 7(3), 218-230.

Balmer, J.M.T. and Greyser, S.A. (2002) 'Managing the Multiple Identities of the Corporation', California Management Review, 44(3), 72-86.

Boyle, M. (2004) 'Walking our talk: Business schools, legitimacy, and citizenship Mary', Business and Society, 43(1), 37-48.

Carroll, A. B. (1999), 'Corporate Social Responsibility', Business \& Society, 38(3), 268-296.

Christensen, L.J.; Peirce, E.; Hartman, L.P.; Hoffman, W.M. and Carrier, J. (2007) 'Ethics, CSR, and Sustainability Education in the Financial Times Top 50 Global Business Schools: Baseline Data and Future Research Directions', Journal of Business Ethics, 73, 347-368.

Corley, K. and Gioia, D. (2000) 'The rankings game: Managing business school reputation', Corporate Reputation Review, 3(4), 319-333.

Cornelissen, J. (2008), Corporate Communication: A Guide to Theory and Practice. London: Sage Publications.

Dawkins, J. (2004), 'Corporate responsibility: The communication challenge'. Journal of Communication Management, 9(2), 108-119.

Durand, T. and Dameron, S. (eds.) (2008), The Future of Business Schools. Scenarios and Strategies for 2020. Houndsmills and New York: Palgrave Macmillan.

Esrock, S. L., \& Leichty, G. B. (1998), 'Social responsibility and corporate webpages: Selfpresentation or agenda setting?', Public Relations Review, 24(3), 305-315.

Esrock, S. L., \& Leichty, G. B. (2000) 'Organisation of corporate webpages: Publics and functions', Public Relations Review, 26(3), 327-344. 
Fombrun, C. (2005) 'Building Corporate Reputation Through CSR Initiatives: Evolving Standards', Corporate Reputation Review, 8(1), 7-11.

Freeman, R. Edward (1984), Strategic Management: A stakeholder approach. Boston: Pitman.

Friedman, M. (1970), 'The social responsibility of business is to increase its profits', The New York Times, (September), 33.

Galbreath, J. (2008), 'Building corporate social responsibility into strategy', European Business Review, 21(2), 109-127.

Habisch, A.; J. Jonker; M. Wegner; R. Schmidpeter (eds.) (2005), Corporate Social Responsibility Across Europe. Berlin: Springer.

Hemsley-Brown, V. \& Oplatka, I. (2006 J).V. 'Universities in a competitive global marketplace: a systematic review of the literature on higher education marketing', International Journal of Public Sector Management 19 (4), 316-338.

Maignan, I.; O.C. Ferrell (2001), 'Corporate citizenship as a marketing instrument. Concepts, evidence and research directions'. European Journal of Marketing, 35(3/4), 457-484.

Matten, D. and Moon, J. (2004) 'Corporate Social Responsibility Education in Europe', Journal of Business Ethics, vol. 54: 323-337.

Matten, D. \& Moon, J. (2008), 'Implicit and explicit CSR: A conceptual framework for a comparative understanding of Corporate Social Responsibility', Academy of Management Review, 33(2), 404-425.

Morsing, M. (2003), 'Conspicuous Responsibility: Communicating Responsibility - To Whom?', in: Morsing, M. \& Thyssen, C. (eds.): Corporate Values and Responsibility. Copenhagen: Samfundslitteratur, 145-154.

Morsing, M.; S.C. Beckmann (Eds.) (2006), Strategic CSR Communication. Copenhagen: Djøf Publishing.

Morsing, M., M. Schultz and K. U. Nielsen (2008), 'The 'Catch 22' of communicating CSR: Findings from a Danish study’, Journal of Marketing Communications, 14(2), 97-111.

Nielsen, A. E. (2005) 'The 'Caring' Corporation - A case study of companies' ethical discourse on the web', in: Klaus Brun Jensen (ed.) Interface ://Culture- The world wide web as political resourse and aesthetic form, Copenhagen: Samfundslitteratur.

Nielsen, A. E. \& Thomsen, C. (2007) 'What they say and how they say it', Corporate Communications: An International Journal, 12(1), 25-40. 
Pollach, I. (2003) 'Communicating Corporate Ethics on the World Wide Web: A Discourse Analysis of Selected Company Web Sites', Business \& Society, 42(2), 277-287.

Pollach, I. (2005) 'Corporate self-presentation on the WWW: Strategies for enhancing usability, credibility and utility', Corporate Communication: An International Journal, vol. 10, no. 4: 285-301.

Schlegelmilch, B. B.; I. Pollach (2005), 'The Perils and Opportunities of Communicating Corporate Ethics', Journal of Marketing Management, 21, 267-290.

Tedeschi, J. T. \& Melburg, V. (1984) 'Impression Management and Influence in the Organiszations', in S.B. Bacharch and E.J. Lawler (eds.): Research in the Socioology of Organiszations, Jai Press, Greenwich CT, 31-58.

Van Riel, C.B.M.; C.J. Fombrun (2007) Essentials of Corporate Communication: Implementing Practices for Effective Reputation Management, Routledge: London.

Vidaver-Cohen, D. (2007) 'Reputation Beyond the Rankings: A Conceptual Framework for Business School Research', Corporate Reputation Review, 10(4), 278-304.

Volkwein, J. Sweitzer, K. (2006). 'Institutional prestige and reputation among research universities and liberal arts colleges', Research in Higher Education, 47(2), 129-148.

Wanderley, L. S. O.; R. Lucian; F. Farache; J. M. de Sousa Filho (2008), 'CSR Information Disclosure on the Web: A Context-Based Approach Analysing the Influence of Country of Origin and Industry Sector'. Journal of Business Ethics 82, 369-378.

Wayen, S. J. \& Liden, R. C. (1995) 'Effects of Impression Management on Performance Appraisal Study', Academy of Management Journal 38 (1), 232-260.

Welcomer, S. A., Cochran, P. L., Rands, G. \& Haggerty, M. (2003) 'Contructing a Web - Effects of Power and Social Responsiveness on Firm-Stakeholder Relationships’, Business \& Society, 42(1), 43-82

Wæraas, A. (2008) 'Can public sector organisations be coherent corporate brands?', Marketing Theory, 8, 205-221. 